\title{
Tekstin semanttiset sidokset ja lähisukukielen ymmärrettävyys
}

\author{
PIRKKO MUIKKU-WERNER \\ Itä-Suomen yliopisto
}

Tiivistelmä. Useat tutkimukset osoittavat, että sukukielten keskinäinen ymmärrettävyys perustuu monitasoiseen samankaltaisuuteen. Voivatko ymmärrettävyyttä edistää myös koherentin tekstin rakentamiseen liittyvät leksikaalis-semanttiset seikat? Johdonmukaisissa teksteissä fraseologisiin yksiköihin sisältyvät käsitteet eivät kytkeydy toisiinsa mielivaltaisesti, vaan kirjoitusten sujuvuuden takaa tiettyjen, ei-kielikohtaisten periaatteiden noudattaminen.

Tekstin yhtenäisyys perustuu osittain siihen, että rinnakkaisilla sanoilla on tapana pohjustaa toistensa esiintymistä. Jos pohjustava sana (prime) on tuttu, lukija saattaa pystyä päättelemään fraasiin liittyvän toisen sanan (target) merkityksen silloinkin, kun tämä toinen lekseemi ei ole tunnistettavissa sukulaisuuden perusteella. Prosessia helpottaa konteksti: myötäesiintymispreferenssi rajoittaa tarjoutuvia vaihtoehtoja ainakin jossain määrin.

Tarkoitukseni on testata, miten tekstin temaattinen koherenttius ja fraasin sisäiset semanttiset sidokset auttavat vieraan sanan ymmärtämistä, jos fraasin jokin konstituentti tiedetään äidinkielen pohjalta. Esittelemässäni pilottitutkimuksessa viroa taitamattomien ei-lingvistien piti kääntää lyhyt teksti ja selittää, miten he olivat päätelleet itselleen tuntemattoman sanan merkityksen. Näyttää siltä, että käsitteen kytkeytyminen toiseen esimerkiksi vastakohtaisuuteen tukeutuen edistää sisällön selvittämistä. Osittain oikea valinta perustunee ei-kielikohtaiseen tietoon, jonka rakenneaineksina on metalingvistisiä käsityksiä tekstin 
koossa pysymisestä, semanttisten kenttien rakenteesta ja sanojen assosioitumisesta toisiinsa.

Avainsanat: reseptiivinen monikielisyys; temaattinen koherenssi; koheesio; fraseologinen yksikkö; kollokaatio; semanttinen pohjustus; viro; suomi

\section{Sukukielen ymmärtämisen näkökulmia}

Kun luemme mitä tahansa vieraskielistä tekstiä, ohitamme aluksi tuntemattomat sanat. Niiden puuttuvan merkityksen löytämiseksi etenemme virkkeen loppuun asti ja toivomme keräävämme riittävästi tietoa ongelman ratkaisuun. Kun pohdimme, miten lähisukukielen (tässä artikkelissa viro) ymmärtäminen onnistuu äidinkielen (suomen) pohjalta, voidaan arvioida paitsi yksittäisten sanojen samanlaisuuteen ${ }^{1}$ nojautumisen tuottamaa hyötyä myös pidempien fraseologisten yksiköiden antamaa tukea. Onhan oletettavissa, että mieleen tulevista leksikaalisista vaihtoehdoista valitaan se, joka rakentaa järjellisen kokonaisuuden muiden (lähi)sanojen kanssa.

Kohdekielisten lekseemien välisiä suhteita ei ole reseptiivisen monikielisyyden tutkimuksessa liiemmälti käsitelty siitä huolimatta, että tunnistetut kytkökset ja merkityksen päättely niiden pohjalta helpottavat esimerkiksi luetun ymmärtämistä. Sen sijaan toisen kielen omaksumisen ja opettamisen yhteydessä sanojen myötäesiintymiin on kiinnitetty huomiota (ks. esim. Bonk 2000 ja Lewis 2000). Seuraavaksi esittelen sellaisia tekstin ominaisuuksia, joiden oletan myötävaikuttavan puuttuvien merkitysten löytämiseen, sekä analyysissä käyttämiäni käsitteitä ja termejä.

Yksittäinen lause saa systeemis-funktionaalisen teorian mukaan merkityksen kolmella tasolla: teksteissä ovat läsnä ideationaalinen, interpersoonainen ja tekstuaalinen metafunktio. Ideationaaliseen metafunk-

\footnotetext{
1 Kontrastiivisessa tutkimuksessa on perinteisesti tarkasteltu yhtäältä suomen ja viron sanastollista ja morfologista samankaltaisuutta, toisaalta suomen ja viron eroja eri näkökulmista (kokoavia katsauksia ks. esim. Remes 2009: 21-38 ja Frick 2013: 18-22).
} 
tioon liittyy muun muassa maailman kuvaaminen ja interpersoonaiseen metafunktioon esimerkiksi sosiaalisten suhteiden vakiinnuttaminen ja ylläpito. Jos oletetaan, että lähitekstillä on tärkeä tehtävä tuntemattoman fraasin merkityksen tunnistamisessa, keskeisessä osassa on tekstuaalinen metafunktio. Se luo sisällöllistä yhtenäisyyttä teksteihin; niille on ominaista looginen jatkuvuus. Kun käsitellään vaikkapa syntymäpäiviä, lahjojen ja vieraiden tuominen tekstiin ei herätä kummastusta. (Metafunktioista ks. Halliday \& Mathiessen 2004: 58-63.) Puhuttaessa tekstin mielekkyydestä käytetään termiä koherenttius, joka ilmenee muun muassa topiikin eheytenä: lauseet liittyvät aiheiltaan toisiinsa. Tekstin pienempien yksiköiden yhteenkuuluvuutta kuvaa termi koheesio, joka perustuu semanttiseen suhteeseen. Sanalla omena ei yksinään ole kohesiivista voimaa, mutta koheesio syntyy, kun omena-sanan edellä tai jäljessä tekstissä esiintyy sana hedelmä (van Dijk 1980: 9; Halliday \& Hasan 1976: 4-10; KK 1994: 73). Koossa pysyvässä tekstissä leksikaalisten elementtien vahva kytkeytyminen toisiinsa voi ulottua yli virkerajan, mutta koheesio voi olla virkkeen sisäistäkin (Hakulinen \& Karlsson 1979: 312).

Koheesiota luodaan monella eri tavalla. Leksikaalinen koheesio syntyy tekstissä käytettävän sanaston yhtenäisyydestä. Paitsi lauseiden osia myös peräkkäisten lauseiden sanoja voivat kiinnittää toisiinsa erilaiset merkityssuhteet. Toisen sanan uskotaan edellyttävän jonkin toisen sanan läsnäoloa, ja tällaista kahden lähekkäin olevan sanan (jopa tilastollisesti merkitsevää) yhteisesiintymistä nimitetään kollokaatioksi. (Firth [1968] 1957: 179; Sinclair 1996: 81; Jantunen 2009: 356.) Kollokointi on seurausta psykologisesta, alitajuisesta prosessista, ja vakiintuneimmat myötäesiintymät ovat osa äidinkielen taitoja (Pace-Sigge 2013: 13-14). Tietyt sanat viihtyvät toistensa kanssa, jolloin syntyy kollokationaalinen koheesio (Halliday \& Hasan 1976: 284-286).

Koheesion yhteydessä voidaan puhua myös pohjustamisesta (engl priming). Sillä tarkoitetaan prosessia, jonka aikana käsitteet ja niiden merkitykset aktivoituvat semanttisessa muistissa (Collins \& Quillian 1972: 119). Tavallisimmin pohjustaminen on leksikaalista: sanaa käytetään tyypillisimmin sen kollokaattien kanssa. Lisäksi jokainen sana 
pohjustaa koko diskurssin koheesiota sekä virittää merkityssuhteita, kuten semanttisia assosiaatioita. (Hoey 2005: 7, 13 ja 2007: 8.) McNamaran (2005: 3-4) mukaan semanttinen pohjustus ilmenee muun muassa siten, että sanaan reagoidaan nopeammin silloin, kun sitä edeltävä ärsykesana kuuluu samaan merkityskenttään (koira kissa; reagointitesteistä ks. myös Neely 1991).

Pohjustus on läsnä monissa kognitiivisissa tehtävissä, kuten nimeämisessä ja semanttisessa luokittelussa. Ärsykkeenä toimivasta sanasta (engl prime) käytän tässä artikkelissa nimitystä pohjustin ja sen avulla pääteltävästä ilmauksesta nimitystä kohdesana (engl target). Kun pohjustin on tunnistettu, siihen liittyvä semanttinen informaatio on käytettävissä ja auttaa löytämään pohjustimen ja kohdesanan yhteisiä merkityspiirteitä. (McNamara 2005: 11, 18, 20.) Pohjustimen ja kohdesanan välinen suhde voi perustua muun muassa täydelliseen tai osittaiseen toistoon, synonymiaan, antonymiaan, meronymiaan (kokonaisuus-osasuhteeseen), hyponymiaan (alakäsite-yläkäsite-suhteeseen) ja muihin kollokaatioihin (Halliday \& Hasan 1976: 285-292).

Kaikki temaattisesti yhtenäiset tekstit rakentuvat paljolti sanojen välisen sidoksisuuden varaan, joka voi pohjata edellisessä kappaleessa mainittuihin semanttisiin suhteisiin. Siten on mahdollista olettaa, että sukukielten keskinäistä ymmärrettävyyttä voi lisätä edistämällä sellaista kielellistä päättelyä, jossa huomio kiinnittyisi sanojen herättämiin mielleyhtymiin ja niiden suosimiin kerasanoihin. Joissain tapauksissahan viron ja suomen samaa merkitsevillä sanoilla on myös samanlaiset kollokaatit.

Hypoteesien testaamiseksi tässä artikkelissa on tarkoitus selvittää,

- onko suomalaisen mahdollista löytää hänelle tuntemattoman virolaisen sanan merkitys sen avulla, mitä hän äidinkielensä ja muiden hallitsemiensa kielten perusteella olettaa tekstielementtien yhteenkuuluvuudesta,

- millaiset käsitykset tekstikokonaisuudesta ja sanojen välisistä merkityssuhteista tuottavat eniten oikeita ratkaisuja sekä mitkä seikat vaikeuttavat niihin päätymistä, ja

- millä tavalla informantit perustelevat ratkaisujaan. 
Vastauksia edellä oleviin kysymyksiin on etsitty suunnittelemalla testi: viroa taitamattomia suomalaisia pyydettiin kääntämään lyhyehkö koherentti teksti, jonka tiettyihin sanoihin heitä kehotettiin kiinnittämään erityistä huomiota. Lisäksi heidän oli selitettävä, miksi he valitsivat kulloisenkin vaihtoehdon. On todennäköistä, että merkityksen löytämiseen vaikuttavat monet tekijät, joten asianomaisten omat näkemykset auttavat tavoittamaan syistä olennaisimpia. Pelkkään käännökseen tutustuminen ei välttämättä paljasta käytettyjä strategioita. Vaikka informanttien määrä on pieni, olen esitellyt joitain tarjottujen ehdokkaiden määrällisiä jakaumia, koska ne havainnollistavat - ainakin suuntaa antavasti ratkaisujen välisiä eroja.

\section{Käännöstestistä ja siihen osallistuneista}

Oletan, että temaattinen yhtenäisyys ja lähekkäin sijaitsevien sanojen väliset semanttiset assosiaatiot edistävät outojen sanojen ymmärtämistä. Tämän oletuksen testaamiseen tarvitaan tekstitehtävä, jossa fraseologisten kokonaisuuksien osasia yhdistävät erilaiset merkityssuhteet. Lisäksi merkitykseltään tuntemattoman vironkielisen sanan lähikontekstissa jonkin lekseemin tai sanaparin toisen jäsenen eli pohjustimen on muistutettava suomenkielistä vastinettaan. Kun äidinkielessä tiettyjen yksiköiden kuuluminen yhteen on tuttua semanttisten suhteiden perusteella, niiden voi olettaa olevan voimassa myös sukukielessä, mikä helpottaa oudon kohdesanan merkityksen arvuuttelua. Alla olevassa tekstissä pohjustin on lihavoitu, kohdesana kursivoitu.

\section{JÕULUD ON UKSE EES}

Kohe on jõulud käes! Jõulu eel ostame kingitusi. Kaunistame kuuse ja mängime selle ümber. Käesoleval aastal ostan sugulastele raamatuid. Üks raamat vöib olla kallis, teine odav.

Katame laua rikkalikult. Sellel on pähkleid ning õlgedest ${ }^{2}$ tähed.

\footnotetext{
2 Alkuperäisessä tekstissä oli epätyypillinen ilmaus ôlgsed tähed, joka oli suomalaisille rakenteellisesti helpompi kombinaatio. Koska kyseinen kohta ei ole kovin relevantti kääntämisen kannalta, asiasta ei kokonaisuuden kannalta koitunut harmia.
} 
Potis on üks hüatsint. See on ilus lill. Peale selle armastan ka roose ja tulpe.

Möödunud jõulu ajal tegime palju pilte. Sellel pildil on minu ema ja õde. Sellel pildil omakorda on minu naine. Ta on rase. Laps sündis juulis. Jõulupühadel on inimestel aega olla perekonnaga.

\section{'JOULU ON OVELLA}

Kohta on joulu! Joulun alla ostamme lahjoja. Koristamme kuusen ja leikimme sen ympärillä. Tänä vuonna ostan sukulaisille kirjoja. Yksi kirja voi olla kallis, toinen halpa.

Katamme pöydän yltäkylläisesti. Sillä on pähkinöitä ja oljista tehtyjä tähtiä. Ruukussa on yksi hyasintti. Se on kaunis kukka. Sen lisäksi rakastan myös ruusuja ja tulppaaneja.

Viime joulun aikaan otimme paljon kuvia. Tässä kuvassa ovat minun äitini ja sisareni. Tässä kuvassa puolestaan on minun vaimoni. Hän on raskaana. Lapsi syntyi heinäkuussa. Joulunpyhinä ihmisillä on aikaa olla perheen kanssa.'

Ensimmäinen kursivoitu sana, kingitusi 'lahjoja', kytkeytyy olennaisesti tekstin teemaan, jouluun. Joulukonteksti edustaa melko pysyvästi jäsentynyttä yhteistä taustatietoa, maailmantietoa, joka auttaa asioiden yhdistämisessä järkeväksi kokonaisuudeksi. Joulu toimii tekstin tulkintakehyksenä. Yleensä kehykset sisältävät stereotyyppistä informaatiota kaikista asiaankuuluvista elementeistä. Joulun tapauksessa osa niistä, kuten jouluruuat ja -lahjat, ovat lähes välttämättömiä, osa taas, kuten joulupukki ja joululaulut, valinnaisia. (Minsky 1975: 212-213; Brown \& Yule 1983: 223-224.) Tekstin kannalta sana joulu toimii pohjustimena; se implikoi useita eri asioita. Sen ja lahjojen välille rakentuu tekstilingvistiikassa käytetyin termein indeksaalinen viittaussuhde (Enkvist 1978: 3).

Tekstilauseen sisäistä yhtenäisyyttä luo myös kahdesta käsitteestä muodostuva vastakohtapari. Käännöstekstissä on kyse antonymiasta, kun pohjustimena toimii kallis ja kohdesanana on odav 'halpa'. Sana lill 'kukka' on puolestaan hyasintin, ruusun ja tulppaanin yläkäsite. Osa edellä mainituista hyponyymeistä edeltää hyperonyymia, osa seuraa sitä. Vieruskäsitteisyyttä ilmentävät kohyponyymit 'ruusuja' (roose) ja 'tulppaaneja' (tulpe). 
Edellisissä tapauksissa toisiinsa sidostuvat lekseemit ovat hyvinkin lähellä toisiaan. Sen sijaan ajallisesti vastakohtaistuvat ilmaukset 'tänä vuonna' (käesoleval aastal) ja 'viime joulun aikaan' (möödunud jõulu ajal) ovat huomattavasti kauempana toisistaan. Toki niiden eriytymistä tukee tekstissä esimerkiksi aikamuotojen vaihtuminen preesensistä imperfektiin, mutta mennyt aika sisältyy vain kahteen verbiin, mikä saattaa hämätä temporaalisten suhteiden havaitsemista.

Perheenjäsenten alakäsitteiden välisistä yhdistelmistä tavallisimpia ovat vastakohtaparit 'äiti' 'isä' ja 'tytär' 'poika'. Myös kombinaatio 'sisar' ja 'veli' on relevantti mutta ei aivan prototyyppisin lähisukulaisuuden kirjaaja. Koska sekä ema että isa ovat suomen pohjalta tunnistettavissa, niitä molempia ei voida käyttää testissä. 'Äiti' ja 'sisar' (óde) tarjoavat kiinnostavan vaihtoehdon stereotyyppisten oletusten todentamiseksi: johtaako pohjustin 'äiti' (ema) kohdesanaan 'isä?' 'Raskaana (rase) olo’ puolestaan edustaa maailmantietoon perustuvaa indeksaalista suhdetta: syntyminen implikoi edeltänyttä odotusaikaa. (Semanttisista suhteista ks. Enkvist 1975: 32-37, 42-45; Larjavaara 2007: 143-152.)

Informantit ovat eri-ikäisiä suomalaisia, jotka ovat olleet tekemisissä viron kielen kanssa vain hyvin satunnaisesti, esimerkiksi Viroon suuntautuneiden matkojen aikana. Kenelläkään ei ole lingvistisiä opintoja, mutta kaikki ovat opiskelleet yhtä tai useampaa vierasta kieltä esimerkiksi koulussa. Useiden kielten hallinta on tärkeä ulottuvuus käännösratkaisuja arvioitaessa, sillä aiempien tutkimusten perusteella on havaittu, että merkitysten etsinnässä hyödynnetään paitsi suku- myös muita osattuja kieliä (ks. esim. Muikku-Werner \& Heinonen 2012: 172-174).

\section{Käsitteellisesti toisiinsa liittyvät nimitykset}

Seuraavaan taulukkoon on listattu kunkin kohdesanan oikeiden käännösten absoluuttiset ja suhteelliset osuudet. Lomakkeissa vastauksen paikalle sijoitettu kysymysmerkki on laskettu vääräksi vaihtoehdoksi. Koska aineisto on pieni, ei esiintymien perusteella voi tehdä yleistäviä 
päätelmiä, mutta tarjottujen käännösvastineiden kirjo on kiinnostava, ja käännösvalintojen mahdollisia syitä voi pohdiskella yksitellen.

TAULUKко 1. Kunkin sanan saamien oikeiden käännösten määrä

\begin{tabular}{|c|c|c|c|c|c|c|c|c|}
\hline 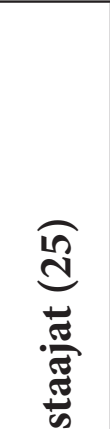 & 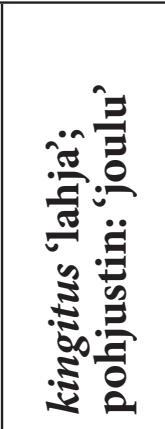 & 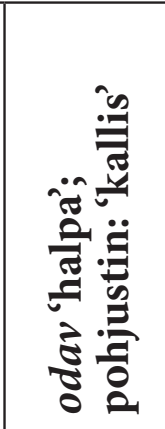 & 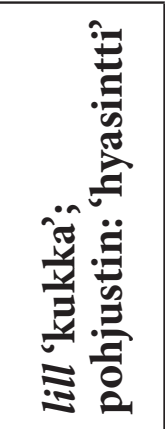 & 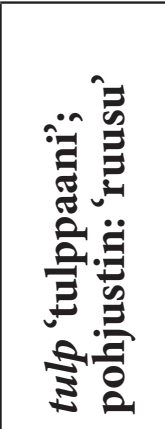 & 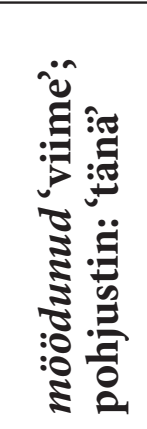 & 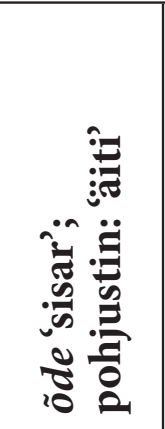 & 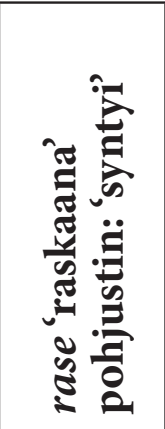 & $\stackrel{\vec{\nexists}}{\dot{\nexists}}$ \\
\hline & abs / \% & abs / \% & abs / \% & abs / \% & abs / \% & abs / \% & abs / \% & abs / \% \\
\hline N 17 & $13 / 76,5$ & $14 / 82,4$ & $8 / 47,1$ & $17 / 100$ & $4 / 23,5$ & $1 / 5,9$ & $7 / 41,2$ & $64 / 53,8$ \\
\hline M 8 & $3 / 37,5$ & $7 / 87,5$ & $2 / 25,0$ & $8 / 100$ & $2 / 25,0$ & - & $1 / 12,5$ & $23 / 41,1$ \\
\hline Yht. & $16 / 64,0$ & $21 / 84,0$ & $10 / 40,0$ & $25 / 100$ & $6 / 24,0$ & $1 / 4,0$ & $8 / 32,0$ & $87 / 49,7$ \\
\hline
\end{tabular}

Taulukon tuloksia tulkittaessa on muistettava, että ymmärtämistä ovat voineet helpottaa myös muut tekijät kuin sanojen väliset semanttiset suhteet. Näitä mahdollisia selittäviä muuttujia voidaan kuitenkin rajata sen nojalla, millaisia syitä informantit itse ovat valinnoilleen esittäneet. Näitä perusteluja käsittelen tarkemmin seuraavassa luvussa.

Kaikki vastaajat ovat osanneet tulkita 'ruusun' (roos) vieruskäsitteen 'tulppaani’ (tulp). Hyvään tulokseen pääsyä edistää ehkä se, että konteksti on melko helppo ja että tulp-sanalla on jonkinasteista samankaltaisuutta yhtäältä suomalaisen, toisaalta saksalaisen vastineensa kanssa (die Tulpe). Myöskään vastakohtapari odav kallis ei tuota kääntäjille suuria ongelmia.

Testiin tarkoituksellisesti sijoitetut riskisanat, "petolliset ystävät" (ks. tarkemmin Laalo 1992; Alvre \& Vodja 1995), kuten kingitus, joka saattaa tuoda mieleen 'kinkun', ja lill, joka muistuttaa suomen sanoja lilja ja lila, osoittautuvat vaikeiksi. Ensimmäisessä tapauksessa hämminkiä aiheuttaa paitsi sukulaissanan yhtäläisyys myös se, että kinkku sopii hyvin pohjustimen 'joulu' kohdesanaksi temaattisen eheyden perusteella ja 
että lahjoja edustavat 'kirjat' eivät ole kohdesanan välittömässä läheisyydessä helpottamassa yläkäsitteen päättelyä. Lauseessa see on ilus lill 'se on kaunis kukka'see-pronominin referentti on yksiselitteisesti hüatsint, minkä uskoisi poistavan riskisanan harhaannuttavan vaikutuksen. Näin ei kuitenkaan käy. Ilmeisesti seuraavassa virkkeessä mainitut ruusut ja tulppaanit toimivat yllykkeenä luetella erilaisia (lempi)kukkia; niiden joukkoon 'lilja' sopii hyvin.

Kuluvan ja edellisen vuoden vertaaminen on yksi tekstin koherenttiutta rakentava tekijä. Silti pohjustin käesolev 'tämä' ja kohdesana möödunud 'viime' ovat sen verran etäällä toisistaan, etteivät erilliset ajankohdat sidostu toisiinsa. Vaikka aikamuodot havainnollistavat nykyisten ja menneiden tapahtumien vaiheittaisuutta, niiden tunnistaminen ei ole itsestään selvää pelkästään äidinkielen pohjalta.

Odotuksenmukaisesti vääriä vastauksia kertyy eniten sanan õde 'sisar' yhteyteen, koska sen luontevin vastakohtapari olisi 'veli'. Tämä tulos kuitenkin omalla tavallaan osoittaa, miten vahvoja semanttiset kytkökset ovat. Kun pohjustimena on 'äiti, rinnasteisen rakenteen toiseksi jäseneksi ei kovin helposti asetu 'sisar', joka perheen rakennehierarkiassa kuuluu eri tasolle.

Keskimäärin naiset (yhteensä 17) päättelevät miehiä (yhteensä 8) useammin kohdesanan merkityksen oikein. Erityisen selkeä on ero rase-sanan vastineiden löytämisessä. Tässä tapauksessahan pohjustin (sündis 'syntyi') on etsittävän sanan jäljessä, mikä saattaa vaikeuttaa kahden lekseemin välisen yhteyden havainnointia (jäljessä tulevasta pohjustamisesta ks. McNamara 2005: 97-103). On kuitenkin huomattava, että kummankin ryhmän edustajia on niukasti, joten tulos kertoo vain tämän aineiston jakaumasta.

Onnistumisen perusteita pohdittaessa voidaan tässä yhteydessä jättää huomiotta ne sanat, joiden kääntäminen "väärin" johtuu liiasta luottamuksesta joko viron ja suomen samankaltaisuuteen (lill $={ }^{\star}$ lila' tai ^’lilja') tai odotuksenmukaisimpaan semanttiseen kytkökseen (ema 'äiti' $\sim \tilde{o d e}={ }^{*}$ ‘isä). Käsittelen niitä taulukon 3 jälkeisessä tekstissä. 
TAuLuкко 2. Oikeiden käännösten määrä (ilman sanoja lill ja õde)

\begin{tabular}{|c|c|c|c|c|c|c|}
\hline 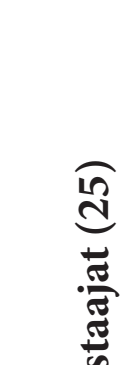 & 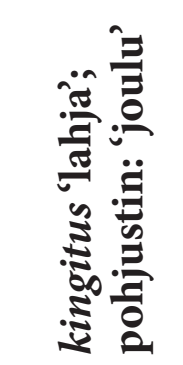 & 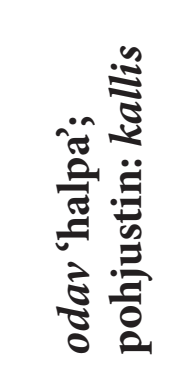 & 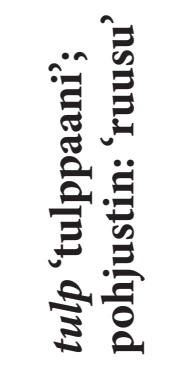 & 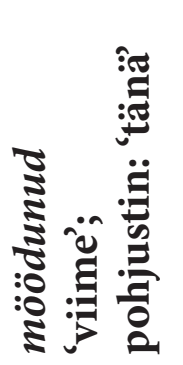 & 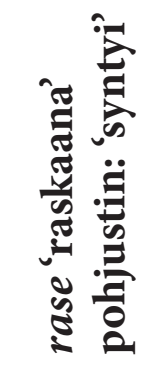 & 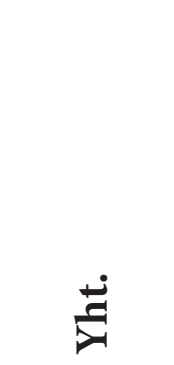 \\
\hline$\stackrel{5}{=}$ & abs / \% & abs / \% & abs / \% & abs / \% & abs / \% & abs / \% \\
\hline N 17 & $13 / 76,5$ & $14 / 82,4$ & $17 / 100$ & $4 / 23,5$ & $7 / 41,2$ & $55 / 73,3$ \\
\hline M 8 & $3 / 37,5$ & $7 / 87,5$ & $8 / 100$ & $2 / 25,0$ & $1 / 12,5$ & $21 / 52,5$ \\
\hline Yht. & $16 / 64,0$ & $21 / 84,0$ & $25 / 100$ & $6 / 24,0$ & $8 / 32,0$ & $76 / 60,8$ \\
\hline
\end{tabular}

Kun testiin tahallisesti valitut tavalla tai toisella harhaanjohtavat ainekset jätetään pois, muiden sanojen osalta virheettömiä vastauksia on selvästi enemmän. Tietysti myös kingitus on riskisana, mutta väärälläkin käännöksellä 'kinkku' on yhteyksiä jouluteemaan, joten merkityksen päättelyyn voi vaikuttaa tämän tutkimusasetelman kannalta keskeinen semanttinen koheesio. Näin ollen tämän riskisanan mukanaolo on perusteltua. Sekä taulukosta 1 että taulukosta 2 ilmenee, että informantit hyödyntävät erilaisia strategioita hyvin: vaikka mukana on vaikeiksi osoittautuneita sanoja, kuten möödunud ja rase, lähes aina vähintään neljännes löytää korrektin vastauksen.

Seuraavasta taulukosta on nähtävissä, millaisia vaihtoehtoja tarjottiin kunkin sanan käännöksiksi. Joissakin tapauksissa olen niputtanut samantyyppisiä merkityksiä yhteen sarakkeeseen. Joitakin sanoja ei ole lainkaan käännetty, minkä vuoksi vastausten yhteissummaksi ei aina tule 25:tä.

Kaikki kolme kingitus-sanan käännöstä liittyvät selvästi jouluteemaan; niistä joka ikinen soveltuu vähintään kehyksen valinnaiseksi piirteeksi. Tarjottujen vaihtoehtojen määrä on niukka, ja riskisana 'kinkku' on monien ehdokas. Paitsi 'kinkun' myös 'kynttilän' valinneiden voi ajatella hahmottaneen tietynasteista yhtäläisyyttä kingitus-sanan kanssa: 'Joulun alla ostamme kinkun' (VA7/M) ja 'Ennen joulua ostamme 


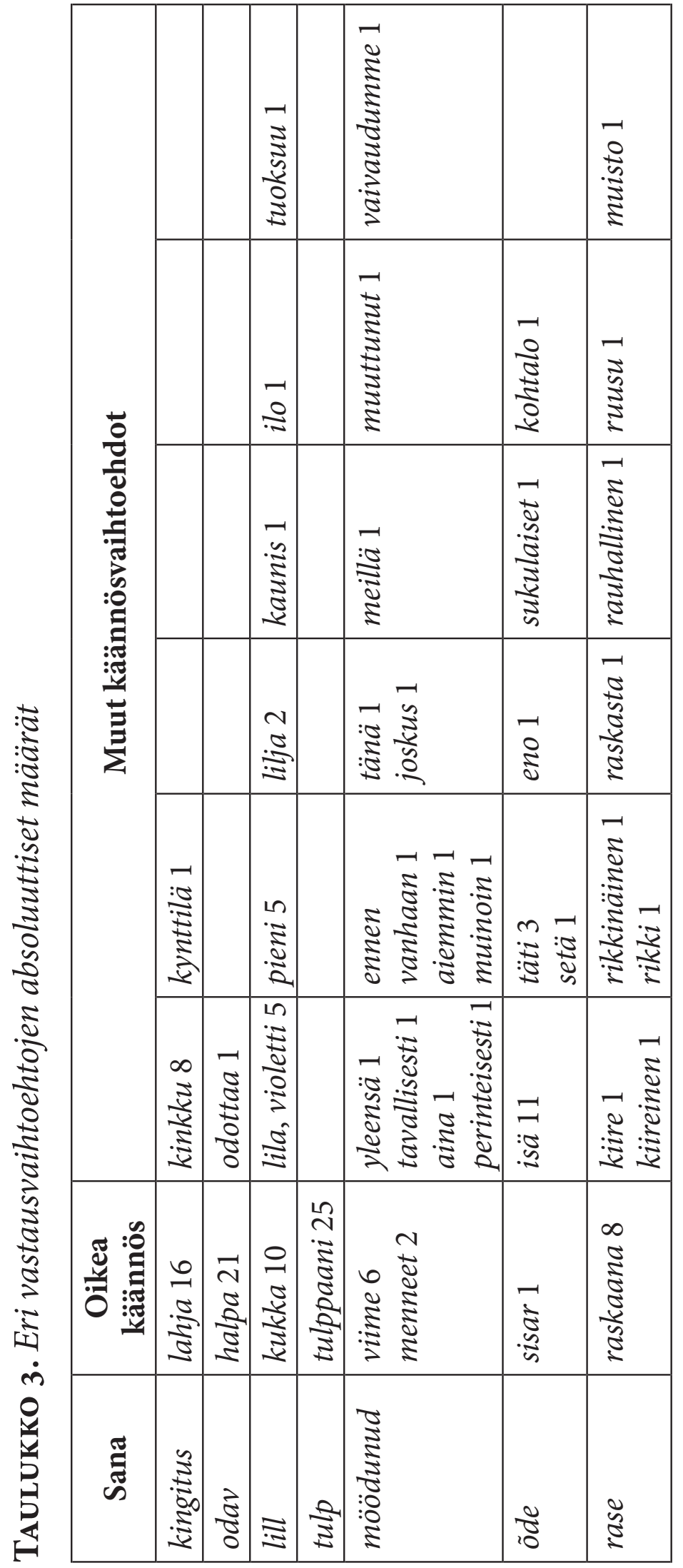


kynttilöitä’ (VA24/M). Aiemmissa leksikaalisen samankaltaisuuden vaikutusta käsittelevissä tutkimuksissa on havaittu, että ymmärtäminen on sitä helpompaa, mitä enemmän vertailtavassa ja sukulaissanassa on samoja kirjaimia (ks. esim. van Bezooijen \& Gooskens 2007: 256). Yhteinen $k$-alkukirjain yksinään tuskin vielä johtaa merkityksen selvittämiseen, mutta tekstissä nimettyjen ilmiöiden yhteenkuuluvuudesta on päättelyssä lisäapua, kuten edellä olevat kommentit todistavat.

'Halpa' kalliin vastakohtana ja 'tulppaani' ruusun vieruskäsitteenä ovat löytyneet ilmeisen helposti. Sen sijaan lill-sanalle ehdotetaan useita vastineita, joista kahdessa, 'lilja' ja 'violetti / lila', korostuu luottamus viron ja suomen samankaltaisuuteen: 'Siinä [ruukussa] on myös yks lilja' (VA4/M) ja 'Se [hyasintti] on iloisen lila' (VA13/N). 'Pieni'-käännös nojautunee ruotsiin (lilla): 'Se on aluksi pieni' (VA19/N). 'Kaunis' on erikoinen valinta, vaikka periaatteessa merkitys olisi poimittavissa lausekkeen ilus (lill) attribuutista. Informantti esittää kuitenkin nimenomaan lill on yhtä kuin 'kaunis' -vastaavuutta: 'Se on kaunis' (VA16/N). Pohjautuuko tarjokas 'ilo' jonkinasteiseen samankaltaisuuteen ilus-sanan kanssa, jää arvailtavaksi (ks. aiempia havaintoja sanan kynttilä yhteydessä). Yleistä luovuutta osoittaa käännös 'Se on ilo silmälle.' (VA5/M). 'Tuoksuu' sijoittuu ympäristöönsä loogisesti: 'Se tuoksuu hyvältä.' (VA6/N). Kaksi jälkimmäistä vaihtoehtoa nojautuvat maailmantietoon, joka rakentuu aistihavaintojen varaan.

Möödunud on osittain kirjoitusasun perusteella yhdistettävissä 'menneeseen': 'Menneenä jouluaikana teimme paljon ruokaa' (VA9/M). Esimerkiksi itämurteissa sanan männä (jouluna tai vuonna) käyttö merkityksessä 'viime' on tavallista. Lauseesta Möödunud jõulu ajal tegime palju pilte syntyy asiallisesti järkevä kokonaisuus myös siinä tapauksessa, jos käytetään tapahtumien toistuvuutta korostavia käännöksiä 'yleensä, 'tavallisesti', 'aina' ja 'perinteisesti', kuten 'Tavallisesti joulun aikaan teimme (?) paljon lapsia' (VA19/N), tai ylipäänsä varhempaan ajankohtaan viittaavia ajanilmauksia kuten 'ennen vanhaan', 'aiemmin' ja 'muinoin': 'Ennen vanhaan joulun aikaan teimme paljon ?' (VA3/N). Jokin käännös saattaa tuottaa täysin toisentyyppisen kontekstin: 'Yleensä 
joulun aikaan teemme paljon vilttejä.' (VA7/M) tai 'Tavallisesti joulun aikaan askartelemme seimen.' (VA4/M). Tekstiin syntyy ajallista kontrastia muun muassa verbin aikamuodon vaihtumisen kautta. Jos se jää huomaamatta, käännökset 'tänä' ja 'joskus' ovat yksi mahdollisuus. Jotkut informanteista tarjoavat 'muuttunut'- ja 'vaivaudumme'-vastineita: 'Muuttuneen joulun aikana tehtiin paljon lapsia' (VA10/N) ja 'Vaivaudumme joulun aikana tekemään paljon kuvia' (VA11/N). 'Muuttunut'käännös pohjannee oletukseen viron ja suomen samankaltaisuudesta.

Odotuksenmukaisesti 'äiti'-pohjustin tuottaa vastakohtapariksi 'isän'. Mitä todennäköisimmin 'isän' noutaminen muistista kerasanaksi perustuu sen suurtaajuiseen myötäesiintymiseen 'äidin’ kanssa (pohjustamisen ja kollokoinnin suhteesta frekvenssiin ks. Pace-Sigge 2013: 31). Muitakin sukulaisia ehdotetaan, mutta 'tätiä' lukuun ottamatta valinnat ovat satunnaisia, vain kerran esitettyjä: 'Tässä kuvassa on minun äitini ja enoni (?).' (VA1/N) ja 'Sellainen [ruuan teko] on minun äidin ja sukulaisten tapana' (VA9/M). 'Kohtalo'-käännöstä ohjaa usko samankaltaisuuteen viron ja ruotsin (õde ja öde) välillä: 'Sellaisissa kuvissa ovat minun äitini ja kohtaloni' (VA11/N).

Rase-sanan ymmärtäminen lauseessa $\mathrm{Ta}$ on rase osoittautuu vaikeaksi. Assosioituminen yhtäältä kiireeseen, toisaalta rikkinäisyyteen tuottaa seuraavan kaltaisia käännöksiä: 'Hän on kiireinen.' (VA8/N) ja 'Tämä on rikki.' (VA17/N). Ehdotus 'Tämä on muisto' (VA18/N) kategorisoi valokuvan uuden luokan alakäsitteeksi. Kiinnostavasti ratkaisuja ohjaa käsitys ta-pronominin laadusta. Jos valitaan persoonapronomini, voidaan kuvitella vaimon kärsivän joulukiireistä; jos taas päädytään demonstratiivipronominiin, edellisestä lauseesta referentiksi poimiutuu (valo)kuva, jonka kehykset tai lasi voi olla rikki tai joka ikuistaa vaimon kyseisenä jouluna. Selvästi on nähtävissä, että nimenomaan edeltävällä tekstillä on suuri merkitys: vaikka seuraavassa lauseessa kerrotaan lapsen syntymästä, ei kaikissa tapauksissa tätä tietoa käytetä hyväksi. Tilanteen 'tyyneys' rakentuu loogisesti silloin, kun käännös sijoittaa tapahtumat aivan toiseen viitekehykseen: '(Yhdellä viltillä on minun vaimoni.) On niin rauhallista.' (VA7/M) 
Johdonmukaisen tekstin rakentaminen onnistuu useimmilta informanteilta. Tuotetut sisällöt paljastavat väärin ymmärtämisen, mutta ne kertovat kuitenkin kyvystä luoda asioiden välille loogisia yhteyksiä ja nähdä fraseologiset yksiköt koherentin tekstin rakenneaineksina. Mikäli merkitysten jäljittämistä halutaan edistää, yksi keino voisi olla lukijan huomion kiinnittäminen lekseemien välisiin suhteisiin: mihin toiseen sanaan kohdesana saattaisi luontevasti assosioitua, ja mikä olisi kyseisen sanan todennäköisin kollokaatti juuri tuossa kontektissa. Lisäksi olisi syytä painottaa, että sekä edeltävän että jäljessä tulevan tekstin yksiköillä voi olla kytköksiä tuntemattomaan sanaan, jonka oikea käännösvastine voi löytyä vasta sitten, kun tarkkailee molemmille puolille sijoittuvaa kontekstia.

\section{Käännösten valintaperusteita}

Edellä olen esitellyt tiettyjen kohdesanojen käännöksiä. Koska niihin päätymisen taustalla on oletettavasti monenlaisia muuttujia, on varmistettava, että nimenomaan semanttiset kytkökset voivat olla yksi merkityksen päättelyn peruste. Seuraavassa kuvaan esimerkkien avulla, millaisia selityksiä informantit antavat ratkaisuilleen.

Testin aiheena on joulu, jonka kehykseen katsotaan kuuluvan sekä välttämättömiä että valinnaisia piirteitä. Monet vastaajat perustelevatkin valintojaan sillä, että tietyt asiat implikoivat toisiaan. Tällöin eivät välttämättä pelkästään lekseemit kytkeydy kiinteästi toisiinsa, vaan myös laaja temaattinen kokonaisuus sidostaa aineksia yhteen. Kuten aiemmin todettiin, kingitus saadaan sovitettua jouluskeemaan vaivatta sekä oikeana käännöksenä 'lahja' että muistuttavuuteen nojautuvana vääränä valintana 'kinkku'. Verbi ostaa sallii objektikseen molemmat:

(1) lahjoja; episodinen muisti ja verbi auttoivat; mitä jouluna ostetaan $(\mathrm{VA} 19 / \mathrm{N})$

(2) lahja > kuningas antaa lahjoja. (VA13/N)

(3) Kinkun monet hankkivat ennen joulua. (VA3/N) 
(4) kingitusi sana muistuttaa suomen kinkkua, ja tuo tulkinta tuntuisi sopivan tähän joulukontekstiin. (VA7/M)

Myös joulun kiireisyys nousee esiin yhtenä vaihtoehtoisena tyypillisenä piirteenä. Jouluun kuuluvat myös tietyt kukat. Vastauksesta (6) on nähtävissä, että päättelyn tulos saattaa olla useamman tekijän summa:

(5) rase - [kiireinen] arvaus kontekstin perusteella (yleensä joulukiireistä puhutaan paljon) (VA8/N)

(6) tulpe - joulu kukka, muistuttaa tietysti suomen tulppaani-sanaa $(\mathrm{VA} 21 / \mathrm{N})$

Jotkin implikaatiot ovat 'universaaleja', ihmisen biologiaan liittyviä itsestäänselvyyksiä. Mikäli rase-sanan merkityksen etsinnässä tukeudutaan jäljessä tulevaan virkkeeseen, lapsen syntymän edellytys on hahmotettavissa:

(7) Päättelin seuraavan lauseen perusteella. (VA14/N)

(8) Jäljessä puhe lapsen syntymästä, varmaan raskaana (VA25/M)

Larjavaara (2007: 146) toteaa, että ihmiset varhaisvaiheestaan asti ovat polaaristaneet maailmaa ja asettaneet asioita vastakkain. Vastakohtaisuus on siis käsitejärjestelmämme perusluonteinen osa. Pohjustimen ja kohdesanan välisen suhteen ollessa antonyyminen oikean ratkaisun löytyminen on helppoa ja ilmiön kuvaaminen ei tuota ongelmia. Kiinnostavaa on se, että informantit vetoavat tässä yhteydessä nimenomaan logiikkaan.

(9) odav: Halpa (ajattelin sen olevan kalliin vastakohta) (VA23/N)

(10) odav = halpa Looginen vastakohta kalliille (VA14/N)

Eräänlainen - tosin vähemmän selvä kuin edellä - vastakohtaisuus rakentuu tekstiin siihen sisältyvien kahden perättäisen joulun tapahtuminen kuvauksesta. Ensimmäinen maininta, käesoleval aastal, saattaa jälkimmäisen sanan vuoksi jäädä ymmärtämättä, jolloin seuraavan ajankohdan, möödunud jõulu ajal, päättelylle ei kovin helposti löydy kronologisen järjestyksen tuomaa tukea. Osa informanteista poimii oikeat ajalliset suhteet erilaisin perustein. Vaikka otettujen valokuvien 
liittyminen menneeseen onkin esimerkin (13) informantille melko selvää, tekstin alkupuolen maininta käsillä olevasta nykyjoulusta vaikeuttaa tapahtumajärjestyksen hahmottamista.

(11) Viime jouluna. Ja kun sitten ilmeisesti puhuttiin kuvista, jotka on jo otettu, niin siitäkin päättelin ettei voi olla tätä joulusta. (VA5/N)

(12) möödunud = viime, edellinen Pättelin asiayhteydestä; ensin puhutaan tästä vuodesta, sitten muistellaan menneitä. (VA14/N)

(13) möödunud - tämä ei kyllä aukene yhtään. Kuulostaa tosin rakenteeltaan verbiltä. Tämä joulu tai nyt jouluna, jos puhuu menneestä, kun kerta esittelee jo otettuja kuvia? Mutta sitten ei täsmää koko tarinaan, kun alussa oli joulu vasta käsillä... (VA22/N)

Õde-sanan virheellisten käännösten suosio osoittaa kaikkein selvimmin, miten vahvasti tietyntyyppinen vastakohtaisuus ohjaa päättelyä. Mitä todennäköisimmin 'äiti'-sanan suurtaajuisin kollokaatti on useissa teksteissä 'isä, mutta asian todistaminen jää seuraavan tutkimuksen tehtäväksi. Muu perheenjäsenyys tulee mieleen vasta toissijaisena kääntämisperusteluna. Yhtä vastaajaa lukuun ottamatta kaikki informantit uskovat kuitenkin tuntemattoman sanan kytkeytyvän edelliseen nimenomaan sukulaisuuden kautta.

(14) óde: Jos ema on äiti nii õde on isä (VA16/N)

(15) õde - äiti-sana on tullut joskus jossain vastaan, mutta isä on arvaus kontekstin perusteella. (ei toisaalta tunnu tutulta, joten mietin jotain muutakin lähisukulaista) $(\mathrm{VA} 8 / \mathrm{N})$

(16) óde: lienee joku sukulainen, varmaankin täti (VA25/M

Myös ylä- ja alakäsitteiden välisen suhteen hahmottaminen edistää ymmärtämistä, jos pohjustin ja kohdesana ovat riittävän lähekkäin. Esimerkissä (18) on eksplikoitu riskisanan harhaanjohtava vaikutus, joka on kuitenkin torjuttu.

(17) lill: kukka - hyasintti, ruusu, tulppaani ... kaikki ovat kukkia (VA5/N)

(18) lill - kukka (Arvasin sanan asiayhteydestä. Mietin ensin liljaa.) $(\mathrm{VA} 1 / \mathrm{N})$ 
Psykolingvistisissä kokeissa on havaittu irrallisten sanojen yhtyvän vahvimmin koordinatiivisesti: suolan pippuriin ja sokeriin (Larjavaara 2007: 157). Semanttisen kentän yläkäsitteellä saattaa siis olla rinnakkaisia alakäsitteitä eli kohyponyymejä. Käännöstestiin osallistuneet rakensivat yhtäältä hyperonyymin 'kukka', toisaalta 'sukulainen', joiden alakäsitteiksi ryhmittivät tuttuja ja tuntemattomia sanoja.

(19) tulp: arvaus että voisi olla kyseessä tulppaani kun lauseessa oli myös roose jota arvasin ruusuksi (VA11/N)

(20) tulp: Puhe on kukista, hyasinteista ja ruusuista, joukkoon sopii tulppaani (VA25/M)

(21) öde - täti (arvaus yhteydestä, joku sukulainen) (VA18/N)

Kaikki käännökset eivät toki perustu selviin semanttisiin suhteisiin. Kiinnostavia ovat erilaiset assosiaatiot. Seuraavissa esimerkeissä informantit yhdistävät kohdesanoihin aistinvaraisia havaintoja. Tässä yhteydessä ei oteta kantaa siihen, ovatko kyseiset kollokaatit tyypillisiä vai eivät. Yhteisesiintymisen frekvenssillä saattaa olla valintoja ohjaava vaikutus.

(22) lill: hyasintit yleensä liloja (VA21/N)

(23) Tuoksuu. Hyasintista tulee mieleen "tuoksu". (VA6/N)

Kuten useat aiemmat tutkimukset (Kaivapalu 2005: 271; Kaivapalu \& Muikku-Werner 2010: 83) osoittavat, viroon ja suomeen tutustuvat luottavat sukukielten jonkinasteiseen identtisyyteen. Tavallisesti oletettu samankaltaisuus on laaja-alaisempaa kuin todellinen (termeistä ks. Ringbom 2007: 7, 25-26). Testiin tarkoituksellisesti sisällytetyt riskisanat johtavatkin odotuksenmukaisesti harhaan. Vaikka kyseessä on luettu teksti, monet vastaajat saattavat lukea tekstiä ääneen itsekseen (ks. esim. Kaivapalu \& Muikku-Werner 2010: 83; Paajanen \& MuikkuWerner 2012: 241). Auditiivisuudella tuntuukin olevan merkitystä tulkinnoissa (27 ja 28). Joskus odotukset muistuttavuudesta ovat niin vahvoja, että merkityssuhteiden varaan perustuvan - tosin tässä yhteydessä virheelliseen tulokseen johtavan - päättelyn ehkäisee ulkoasun 'sopimattomuus' (29). 
(24) lill: lilja, ...muistuttaa ulkoisesti ko. sanaa. (VA4/M)

(25) möödunud: äänteellinen yhteys suom. menneeseen, aikamuoto $(\mathrm{VA} 23 / \mathrm{N})$

(26) rase: vois olla samaa kantaa kuin rasa räsä (VA29/N)

(27) kingitusi: kuullostaa kinkulta. (VA9/M)

(28) rase: Kuulostaa vähän suomen rauhalliselta, --- (VA7/N)

(29) õde: Mieli teki kontekstin perusteella arvata 'isä, mutta kun sana ei ole yhtään sen näköinen (VA20/M)

Aina lähtökohtana ei ole suomi, vaan myös vieraat kielet ovat yhdenmukaisuuden hakemisen lähde. Lainasuhteita etsitään varsin monesta suunnasta. Samankaltaisia havaintoja on tehty aiemmissakin virolaisen tekstin kääntämiseen keskittyvissä tutkimuksissa (ks. esim. MuikkuWerner \& Heinonen 2012: 179; Paajanen \& Muikku-Werner 2012: 238).

(30) lill muistuttaa ruotsin pientä (VA7/M)

(31) tulp: Saksa kielen die Tulpe -sanasta päättelin (VA15/M)

(32) Sana õde vaikutti vähän sanalta eno. Englannin uncle tuli myös mieleeni. (VA1/N)

(33) [õde] --- ruotsiksi sana tarkoittaa kohtaloa joten käänsin sen niin vaikka ei sopinut lauseeseen. (VA11/N)

Myös kieliopillinen muoto saattaa ohjata oikeille jäljille (ks. esim. Remes 2009: 258-259; Kaivapalu \& Muikku-Werner 2010: 79). Tämäntapaiset vastaukset ovat kiinnostavia, koska taustalla voi olla ajatus vieraan kielen oppimisesta morfologisten piirteiden kontrastoinnin perusteella.

(34) Jos tegime olis imperfektimuoto, voisi sana viitata menneisyyteen (VA8/N)

(35) viime, selvästi partisiippi, varmaankin "mennyt" (VA25/M)

(36) Muuttunut. Lopputaivutus vihjaa tuohon muotoon ja merkitykseen, joka sopii lauseyhteyteenkin. (VA 10/N)

Alussa - ehkä omien kokemusten perusteella - oletin tuntemattoman sanan etsinnässä tukeuduttavan koko tekstin läpi käymiseen. Testissä vain yksi vastaajista korostaa kokonaisuuden merkitystä. Tämä ei tietysti tarkoita, että hän olisi ainoa: pyyntö irrallisten sanojen selittämisestä on voinut johtaa nimenomaan lyhyiden jaksojen tarkkailuun. 
(37) möödunud - viime/menneenä. Koetin arvata, kun olin lukenut tekstin loppuun saakka. En olisi osannut ajatella ollenkaan tätä vaihtoehtoa, jos sana olisi ollut muussa yhteydessä. (VA1/N)

(38) rase - raskaana. Arvasin, kun olin lukenut tekstin loppuun saakka. En olisi osannut ajatella raskautta, jos sana olisi ollut muussa yhteydessä. Silloin olisin ajatellut sanoja rotu tai raskas. (VA1/N)

Vaikka informantit eivät olekaan osallistuneet viron muodolliseen opetukseen, joissain tapauksissa yksittäiset sanat saattavat olla tuttuja. $\mathrm{Ne}$ jäävät mieleen pikaisenkin kielikontaktin yhteydessä, jos käsitteelle on käyttöä.

(39) Hassut nimet kuten "ilusalong" ja "lillepood" ovat jääneet mieleen. (VA14/N)

(40) kingitusi - lahjoja (Arvasin sanan asiayhteydestä. Muistelen lisäksi kohdanneeni sanan Virossa ostoksilla käydessäni.) (VA1/N)

(41) lill - muistan virolaisesta lasten muistipelistä + kukkakioskeista Virossa (VA8/N)

Edellä esitellyt havainnot osoittavat, että suuri merkitys sukukielen ymmärtämisprosessissa on lingvistisellä tiedolla, johon sisältyy monenlaisia aineksia, kuten vieraiden kielten hallintaa (ks. vastaavista tuloksista Hufeisen \& Marx 2007: 308; Singer 2007: 343). Tavallisimmin huomio kiinnittyy nimenomaan sanastoon ja muotoihin, mutta se kohdistuu myös tekstuaalisiin seikkoihin: millainen on temaattisesti yhtenäisen tekstin rakenne, ja miten sanaparit muodostuvat. Informanttien käyttämistä perusteluista on selvästi nähtävissä tämänsuuntaisia yleisiä linjauksia; ne eivät jää yksittäisiksi toteamuksiksi.

\section{Tulemia}

Tekstinymmärtämistestissä oikeaan käännökseen voidaan päätyä muutenkin kuin sukukielisen ja lähtökielisen lekseemin samankaltaisuuden avulla, vaikka samankaltaisuus on tärkeä reseptiivisen monikielisyyden osatekijä. Toisaalta myös semanttisella tasolla toisiaan muistuttavien piirteiden havainnoinnista on hyötyä. Yhtäältä sanojen väliset 
suhteet - antonymia, hyperonymia, indeksaalisuus jne. - ovat tuttuja äidinkielen pohjalta, mutta toisaalta erilaiset kohesiivisuutta rakentavat kombinaatiot ovat melko universaaleja. On siis ajateltavissa, että merkitystä päätellessään koehenkilö voi käyttää hyväkseen kaikkia hallitsemiaan kieliä.

Vierussanojen tai muuten kytköksissä olevien käsitteiden toisen parin (kohdesanan) löytämisen edellytyksenä on se, että toinen (pohjustin) on tuttu kielisukulaisuuden perusteella. Silti aina ei voi olla varma siitä, onko oikeaan käännösvastineeseen johtanut juuri se lekseemi, jonka testin laatija on ajatellut toimivan pohjustimena. Myös koko muu konteksti saattaa tukea tekstin ymmärtämistä. Informanttien ratkaisuilleen kirjaamat selitykset osoittavat kuitenkin sen, että erilaiset semanttiset sidokset edistävät tuntemattoman sanan merkityksen päättelyä.

Oikeaan tulokseen vievä kielellinen päättely voi siis perustua merkityssuhteisiin. Silti yksittäiset tapaukset osoittavat, että joidenkin taustamuuttujien vaikutus voi olla niin vahva, ettei tekstiyksiköiden semanttinen yhteenkuuluvuus ole ensisijainen käännösratkaisujen syy. Riskisana saattaa edelleen johtaa harhaan, mikäli konteksti sallii (kingitusi *'kinkku', lill *'lilja'). Kun kehys on riittävän suppea, kelvollisten vaihtoehtojen määrä vähenee: esimerkiksi ylioppilasjuhliin 'kinkku', toisin kuin 'lahja', ei kuulu. Toisaalta joissain tapauksissa nimenomaan leksikaalinen preferenssi ohjaa valintaa: 'äiti' yhdistyy ensisijaisesti 'isään'. Tällaiset tapaukset ovat yhtä kiinnostavia kuin ne, joissa päädytään oikeaan käännösvastineeseen, mutta ne kaipaavat lähempää tarkastelua.

Tutkimuksen seuraavassa vaiheessa onkin tarkoitus ensinnä selvittää, edistääkö pohjustimen ja kohdesanan välisen 'fyysisen' etäisyyden lyhentäminen jälkimmäisen merkityksen löytymistä (pohjustimen ja kohdesanan etäisyyden merkityksestä ks. McNamara 2005: 91-95). Jos esimerkiksi riskisanan kingitusi välittömään läheisyyteen tuodaan joulukokonaisuuden vaikutusta tehostamaan yläkäsite-alakäsite-asetelma, 'lahja' 'kirja', lisääntyykö oikeiden vaihtoehtojen määrä?

Toiseksi on syytä vielä kokeilla yllä kuvatun kaltaista "läheisyyttä” mutta sellaista kontekstia, jossa 'kinkku'-merkitys ei tue tekstin 
johdonmukaisuutta - esimerkiksi syntymäpäiviä käsittelevää tekstiä. Aiemmat tutkimuksethan osoittavat, että ko- ja konteksti auttavat merkittävästi rakentamaan yhtenäistä tekstiä ja ymmärtämään sen sanoja oikein, jopa riskisanojen harhauttavasta vaikutuksesta huolimatta (Paajanen 2012: 68; Muikku-Werner 2013: 231).

Kolmanneksi olisi hyvä tietää, onko frekventeimmän käännösehdokkaan ja pohjustimen yhteisesiintyminen suurtaajuista myös suuremmassa aineistossa eli onko niiden välinen kollokatiivinen koheesio erityisen vahva yleisestikin. Tällainen erikoisasema näyttäisi olevan sanalla 'isä, joka on suosittu tarjokas sanan õde 'sisar' käännökseksi, silloin kun pohjustimena on sana ema. Helpottuuko oikeaan ratkaisuun päätyminen, jos 'sisar' on asetettu vastakohtasuhteeseen 'veljen' (vend) kanssa, tai nostaako pohjustin isa puolestaan 'äidin' ehdotettujen ratkaisujen kärkeen? Lisäselvitystä kaipaa myös se, vaikuttaako merkityksen valintaan esimerkiksi pohjustimeen liittyvien kollokaattien määrä tai laatu. Onko esimerkiksi pohjustimen 'äiti' kerasanana 'isä' yhtä suurtaajuinen kuin pohjustimen 'isä' kerasanana äiti'?

Edellä mainittujen tarkennusten avulla voidaan selvittää, onko käännösten taustalla vaikuttavilla muuttujilla joitain keskinäisiä etusijaisuuksia: tuottaako vastakohtaisuus ('veli' 'sisar') todennäköisemmin oikean vastauksen kuin väljempi kuuluminen samaan semanttiseen luokkaan ('perhe')? Jotta tulosten luotettavuus lisääntyisi, on syytä testata käännösvastineiden esiintymiserojen tilastollinen merkitsevyys. Todennäköisesti ymmärtämisen laatuun on osallisena monia tekijöitä, mutta niistä joidenkin riippuvuus toisistaan on verifioitavissa.

Leksikaalinen, yksilöidymmin kollokationaalinen kompetenssi sekä siihen kytkeytyvä taito hyödyntää semanttista pohjustusta voisivat olla hyödyksi lähisukukielen ymmärtämisstrategiana. Kun totunnaisesti on turvauduttu ennen kaikkea lekseemin ulkoiseen yhtäläisyyteen merkityksen päättelyssä, uutena ulottuvuutena olisi ei-kielikohtaisten, universaalien fraasirakenteiden sekä semanttisten suhteiden samankaltaisuuden hyväksikäyttö. Periaatteessahan tämä strategia toimii myös siinä tapauksessa, etteivät L1 ja L2 ole sukukieliä, kun vain kohdekielen 
alkeet ovat hallinnassa sen verran, että päättelyn mahdollistava pohjustin tunnistetaan.

\section{Kiitokset}

Kiitän kollegoitani Annekatrin Kaivapalua ja Hannu Remestä kaikista viron kieleen liittyvistä ohjeista ja tekstini kahta arvioijaa hyödyllisistä kommenteista.

\section{Lähteet}

Alvre, Paul, Raul Vodja 1995. Pulma poikineen. Virolais-suomalainen vertailusanakirja ['A problem with its brood: Finnish-Estonian comparison dictionary']. Helsinki: WSOY.

Bonk, William 2000. Testing ESL Learners' Knowledge of Collocations. Illinois: Clearinghouse.

Brown, Gillian, George Yule 1983. Discourse Analysis. Cambridge: Cambridge University Press. http://dx.doi.org/10.1017/CBO9780511805226

Collins, Alan M., R. Michael Quillian 1972. Experiments on semantic memory and language comprehension. - Lee W. Gregg (Ed.). Cognition in Learning and Memory. New York: Wiley, 117-137.

Enkvist, Nils Erik 1975. Tekstilingvistiikan peruskäsitteitä ['Fundaments of Textual Linguistics']. Helsinki: Gaudeamus.

Firth, John Rupert [1968] 1957. A synopsis of linguistic theory, 1930-55. - Frank Robert Palmer (Ed.). Selected Papers of J. R. Firth 1952-59. London: Longman, 168-205.

Frick, Maria 2013. Emergent Bilingual Constructions - Finnish-Estonian Codeswitching in Interaction. $\mathrm{PhD}$ thesis. Helsinki: University of Helsinki.

Hakulinen, Auli, Fred Karlsson 1979. Nykysuomen lauseoppia [Modern Finnish Syntax]. Jyväskylä: Suomalaisen Kirjallisuuden Seura.

Halliday, Michael A. K., Ruqaiya Hasan 1976. Cohesion in English. London: Longman.

Halliday, Michael A. K., Christian M. I. M. Mathiessen 2004. An Introduction to Functional Grammar. Second edition. London: Arnold.

Hoey, Michael 2005. Lexical Priming. A New Theory of Words and Language. London: Routledge. 
Hoey, Michael 2007. Lexical priming and literary creativity. - Michael Hoey, Michaela Mahlberg, Michael Stubbs, Wolfgang Teubert (Eds.). Text, Discourse and Corpora. Theory and Analysis. London: Continuum, 7-29.

Hufeisen, Britta, Nicole Marx 2007. How can DaFnE and EuroComGerm contribute to the concept of receptive multilingualism. - Jan D. ten Thije, Ludger Zeevaert (Eds.). Receptive Multilingualism. Linguistic Analyses, Language Policies and Didactic Concepts. Amsterdam-Philadelphia: John Benjamins, 307-321.

Jantunen, Jarmo 2009. "Minulla on aivan paljon rahaa” - Fraseologiset yksiköt suomenkielen opetuksessa ['I have really lots of money' - Phraseological units in the teaching of Finnish']. - Virittäjä 113 (3), 356-381.

Kaivapalu, Annekatrin 2005. Lähdekieli kielenoppimisen apuna ['Contribution L1 to foreign language acquisition']. Jyväskylä Studies in Humanities 44. Jyväskylä: Jyväskylän yliopisto.

Kaivapalu, Annekatrin, Pirkko Muikku-Werner 2010. Reseptiivinen monikielisyys: miten suomenkielinen oppija ymmärtää viroa äidinkielensä pohjalta? ['Receptive multilingualism: how Finnish as a first language helps learners to understand Estonian?']. - Lähivõrdlusi. Lähivertailuja 20, 68-97. http:// dx.doi.org/10.5128/LV20.03

KK $=$ Kieli ja sen kieliopit. Opetuksen suuntaviivoja. Helsinki: Painatuskeskus, 1994.

Larjavaara, Matti 2007. Pragmasemantiikka ['Pragma-semantics']. Helsinki: Suomalaisen Kirjallisuuden Seura.

Laalo, Klaus 1992. Huvitav lugu - kiinnostava juttu. Suomen ja viron välinen sanaston riskiryhmä ja sen tausta ['Risk Words Between Finnish and Estonian and Their Background']. Suomi 164. Helsinki: Suomalaisen Kirjallisuuden Seura.

Lewis, Michael (Ed.). 2000. Teaching Collocation: Further Developments in the Lexical Approach. Hove: Language Teaching Publications.

McNamara, Timothy P. 2005. Semantic Priming. Perspectives from Memory and Word Recognition. New York: Psychology Press. http://dx.doi. org/10.4324/9780203338001

Minsky, Marvin 1975. A framework for representing knowledge. - Patrick Winston (Ed.). The Psychology of Computer Vision. New York: MacGraw-Hill, 211-277.

Muikku-Werner, Pirkko 2013. Vironkielisen tekstin ymmärtäminen suomen kielen pohjalta ['Understanding Estonian texts on a Finnish language base']. Lähivõrdlusi. Lähivertailuja 23, 210-237. http://dx.doi.org/10.5128/LV23.09 
Muikku-Werner, Pirkko, Maria Heinonen 2012. Lumesadu - 'tarina' vai 'lumikasa' vai ei kumpikaan? Suomalaiset lukiolaiset viron sanoja tunnistamassa [“'Lumesadu” - 'tarina' or 'lumikasa' or something completely different? How Finnish senior high school students try to recognise Estonian words']. - Lähivõrdlusi. Lähivertailuja 22, 157-187. http://dx.doi. org/10.5128/LV22.06

Neely, James H. 1991. Semantic priming effects in visual word recognition: A selective review of current findings and theories. - Derek Besner, Glyn W. Humphreys (Eds.). Basic Progresses in Reading and Visual Word Recognition. Hillsdale, NJ: Erlbaum, 264-333.

Paajanen, Ilona 2012. Kitsas tee - 'laiha tee' vai 'kapea tie'? Suomen kielen opiskelijat ja viron ymmärtäminen testissä ['Finnish students comprehending written Estonian']. Julkaisematon pro gradu -tutkielma. Itä-Suomen yliopisto.

Paajanen, Ilona, Pirkko Muikku-Werner 2012. Tee on kitsas - onko 'tee kitkerää' vai oletteko 'te saita'? Suomalaiset opiskelijat viroa ymmärtämässä [“'Tee on kitsas” - is 'tea bitter' or are you 'penny-pinching'? Finnish students comprehending Estonian']. - Lähivõrdlusi. Lähivertailuja 22, 219-258. http://dx.doi.org/10.5128/LV22.08

Pace-Sigge, Michael 2013. The concept of lexical priming in the context of language use. - ICAME Journal 37, 149-173.

Remes, Hannu 2009. Muodot kontrastissa. Suomen ja viron vertailevaa taivutusmorfologiaa ['Forms in contrast. A Contrastive study of inflectional morphology in Finnish and Estonian']. Acta Universitatis Ouluensis B Humaniora 90. Oulu: Oulun yliopisto.

Ringbom, Håkan 2007. Cross-linguistic Similarity in Foreign Language Learning. Clevedon: Multilingual Matters LTD.

Sinclair, John 1996. The search for units of meaning. - Textus IX, 75-106.

Singer, Murray 2007. Inference processing in discourse comprehension. M. Gareth Gaskell (Ed.). The Oxford Handbook of Psycholinguistics. Oxford: University Press, 343-359.

van Bezooijen, Renée, Charlotte Gooskens 2007. Interlingual text comprehension. Linguistic and extralinguistic determinants. - Jan D. ten Thije, Ludger Zeevaert (Eds.). Receptive Multilingualism. Linguistic Analyses, Language Policies and Didactic Concepts. Amsterdam-Philadelphia: John Benjamins, 249-264.

van Dijk, Teun A. 1980. Text and Context: Explorations in the Semantics and Pragmatics of Discourse. London-New York: Longman. 


\title{
Semantic cohesion and the intelligibility of closely related language
}

\author{
PIRKKO MUIKKU-WERNER \\ University of Eastern Finland
}

Similarity between closely related languages creates the prerequisites for mutual intelligibility. An interesting question is whether the comprehension of texts in a related language relies on lexical-semantic features which create text coherence. In logically built texts, the concepts connected in phraseological units are not linked with each other arbitrarily; rather, the cohesiveness of the text is based on language-independent principles.

The coherence of a text is partly built on the collocational relationship of lexemes, in which a particular word, a prime, provides the semantic context for the lexical decision to the second word, the subsequent target. In a relatedlanguage comprehension task, if the prime is familiar on the basis of the reader's L1, the reader may be able to infer the meaning of the other word (target) even if the target is not cognate with its L1 equivalent and therefore not immediately recognizable. The process is facilitated by context: collocational preferences limit the available alternatives at least to some degree.

The aim of this study was to find out what types of semantic relationships or associations facilitate the understanding of an unknown expression in a related language if it is textually connected to another word which the reader can recognize on the basis of his/her mother tongue. In this pilot study, Finnish-speaking non-linguists without any proficiency in Estonian had to translate a short Estonian text into Finnish and explain their choices of translation equivalents for certain words. The results show that connections between lexemes, for example relational antonym pairs, make the target word easier to understand. Correct translations also rely on encyclopedic knowledge: metalinguistic conceptions of coherent texts and the structure of semantic fields.

Keywords: receptive multilingualism; phraseological unit; thematic coherence; collocation; priming; Estonian; Finnish 


\section{Pirkko Muikku-Werner}

Itä-Suomen yliopiston humanistinen osasto, suomen kieli ja kulttuuritieteet

PL 111

FI- 80101 Joensuu, Finland

pirkko.muikku-werner@uef.fi 